\title{
Hotel Room Cleaning: Time Study and Analysis of Influential Variables in a Spanish Hotel
}

\author{
Victor G. Aguilar-Escobar ${ }^{1}$ (D), Pedro Garrido-Vega ${ }^{1}$ (D) Julián Majado-Márquez ${ }^{2}$ (D), \\ José Antonio Camuñez-Ruiz ${ }^{1}$ iD \\ ${ }^{1}$ Universidad de Sevilla, Departamento de Economía Financiera y Dirección de Operaciones, Facultad de Turismo y Finanzas (Spain) \\ ${ }^{2}$ Universidad de Sevilla (Spain) \\ victorg@us.es,pgarrido@us.es,j.majado@hotmail.com,camunez@us.es
}

Received: December 2020

Accepted: June 2021

\section{Abstract:}

Purpose: Housekeeping is an important hotel process from the point-of-view of the number of work hours it takes and its impact on customer satisfaction. However, few previous scientific studies have addressed this topic or the variables that are determinants of the time required to clean a room.

Design/methodology/approach: A stopwatch Time Study has been performed in a 4-star-hotel. Additionally, data on several variables that could affect cleaning time have been collected and subjected to regression analysis.

Findings: Results show that only the task-related variables have a statistically significant influence on total cleaning time. None of the analyzed employee-related variables have any effect on cleaning time. Moreover, five tasks represent over $2 / 3$ of the total cleaning time.

Originality/value: In addition to empirically identifying the variables that influence cleaning time and to what extent, this study demonstrates the advantages of using stopwatch time studies to establish cleaning times.

Keywords: hotel management, housekeeping, room cleaning, time study, regression analysis

\section{To cite this article:}

Aguilar-Escobar, V.G., Garrido-Vega, P., Majado-Márquez, J., \& Camuñez-Ruiz, J.A. (2021). Hotel room cleaning: Time study and analysis of influential variables in a Spanish hotel. Journal of Industrial Engineering and Management, 14(3), 645-660. https://doi.org/10.3926/jiem.3441

\section{Introduction}

The purpose of this paper is to study hotel room cleaning time and analyze the main variables that determine the time required. Room cleaning is the responsibility of the hotel's housekeeping department and numerous empirical studies have proven the major importance of this department for customer satisfaction, perceived quality, and loyalty. For example, in a study of four business hotels, Gundersen, Heide and Olsson (1996) found that tangible aspects of the housekeeping department and intangible aspects of the reception department had the strongest impact on overall satisfaction. Lockyer (2003) stated that many studies report strong evidence that cleanliness is a 
very important factor in the selection of accommodation. In a survey of three hotel chains, Hartline, Wooldridge and Jones (2003) concluded that only front-desk and housekeeping performance have a positive and significant impact on guests' perceived service quality. Another survey by Lewis and McCann (2004) found that clean and comfortable bedrooms are the leading service quality attribute for hotel guest respondents. Meanwhile, Pongsiri (2012: page 346) concluded that it has been "clearly demonstrated that the expectation and importance of the housekeeping service are related to customer satisfaction". In an analysis of the factors that affect the quality of service in Taiwan hotels, Chen and Chen (2014) found that cleanliness of both the rooms and the restaurants are attributes of the quality of service and the positive perception of a hotel's corporate image. Similarly, in their analysis of 12 activities in hotels, Espino-Rodríguez and Ramírez-Fierro (2017) found that room cleaning can be considered one of the core competencies due to its impact on competitive advantage. Robinson, Kralj, Solner, Goh and Callan (2016) argued that, along with front office and food and beverage staff, being a housekeeping employee can be considered a frontline occupation to a certain extent and that frontline staff play a key role in the success of a service organization. A recent study by Hsieh and Chuang (2020) has shown that environmental quality is the second key factor for service experience in hotels and that cleanliness comes first when customers evaluate the quality of their service experience. In Spain, the hotel cleanliness is one of the seven requisites for obtaining the ICTE (Institute for Spanish Tourist Quality) Q certificate, which is similar to ISO 9001 (Pereira-Moliner \& Tarí, 2015; Nicolau \& Sellers, 2011). Zemke, Neal, Shoemaker and Kirsch (2015) go one step further and propose that hotel companies explore improving cleanliness as an amenity and consider the option of turning enhanced cleanliness into a company strength and a marketing argument.

In terms of employment, the housekeeping department accounts for approximately $26 \%$ of all hotel employees (Krause, Scherzer \& Rugulies, 2005). More generally, cleaning activities account for more than $8 \%$ of all jobs in France (Abasabanye, Bailly \& Devetter, 2018) and over 4 billion euros are spent on cleaning every year in The Netherlands alone (Vlijmen, 2019). Digging deeper into the importance of this activity, an estimate can be made of the number of times that this task is performed per year. If on average 23.51 million rooms were offered per day worldwide in 2015 (World Tourism Organization, 2017) with an average occupancy rate of $60.51 \%$ (ibid.), it can be deduced that approximately 5,194 million rooms were cleaned in that year. If it is estimated that 0.5 hours is required per room (including breaks, transportation, etc.), room cleaning generated a workload of approx. 2,597 million work hours worldwide in the said year. In contrast, if each of the 90,843,939 vehicles produced in the world in 2015 (OICA - International Organization of Motor Vehicle Manufacturers, 2016) required an estimated average of 20 hours for assembly, together they generated a workload of approx. 1,817 million work hours. However, while it is possible to find a large number of studies in the academic literature that address industrial activities and the time required to execute each of the tasks and sub-tasks of which a job is composed, there are hardly any that address the activity of room cleaning and studies measuring the time involved are especially scarce.

Research on cleanliness in general, and on hotel room cleaning in particular, is quite sparse. A good part of the literature that exists focuses on ethical or sociological aspects related to its consideration as "dirty work", its social invisibility, feminization of the sector, the role of immigrants, etc. (Vlijmen, 2019; Abasabanye et al., 2018; Soni-Sinha \& Yates, 2013; Onsøyen \& Mykletun, 2009). Other studies focus on aspects of occupational health and safety (Oxenbridge \& Lindegaard-Moensted, 2011; Goggins, 2007; Krause et al., 2005; Zock, 2005) such as occupational risks (musculoskeletal diseases, poisoning, falls, etc.). There are also works on cleaning from the customer's point of view, for example, on how it affects their satisfaction or service experience, what importance they attach to it and how they value it, etc. (Manhas, 2015; Lockyer, 2003; Sherman, 2011). However, there are very few studies that have focused on how to measure cleaning times and the variables that influence them. There are some works that mention room cleaning times but without specifying how they are obtained, while others mention factors that influence cleaning time but without empirically studying the relationship. To the best of our knowledge, the only time study conducted to determine room cleaning time is Mehrez, Israeli and Haddad (2000), which analyzes the case of a single hotel in Israel. This study can also be considered a precedent to Jones and Siag (2009), although in this case the number of rooms per hour is used as a measure of productivity in a study of 45 hotels in the United Kingdom owned by the same company. Therefore, given the limited number of previous studies and having demonstrated the importance of hotel room cleaning, the present research study pursues a dual objective: 
1. To show how the stopwatch Time Study technique could be used to calculate room cleaning times and what its advantages are,

2. To identify the variables that influence hotel room cleaning time.

The remainder of the paper is structured as follows. First, an overview is given of the previous research on the topic and some hypotheses are proposed. Second, the methodology used to obtain time estimations and all the data on cleaning are described and analysis techniques are explained. Next, the main results are presented, divided into two subsections, one per each of the objectives. Finally, the results are discussed, and the main conclusions are drawn, highlighting theoretical and managerial implications and the limitations of the study.

\section{Background and Research Hypotheses}

The housekeeping department's most important activity is room cleaning. This is a repetitive task performed by housekeepers/chambermaids. Despite its importance, room cleaning does not seem to have sparked much interest in the research. This lack of interest also extends to the cleaning sector in general and, according to Vlijmen (2019), the limited existing research on facility cleaning is focused on technical aspects, such as efficiency and cost reduction, and the organization of cleaning. This may be due to the fact that cleaning does not enjoy the same status in hotels as other activities (Boon, 2007); in fact, cleaners command little status in the eyes of managers and fellow workers (Robinson et al. 2016). Also, cleaners in general are regularly subject to social invisibility and branded by dirty work stigma (Vlijmen, 2019). Thus, several authors have shown that hotel housekeeping work is low paid (Frumin, Moriarty, Vossenas, Halpin, Orris, Krause et al., 2006; Eriksson \& Li, 2009), while others emphasize that it is a job with significant occupational risks (Krause et al., 2005; Frumin et al., 2006). Additionally, the work has been subject to considerable pressure and stress in recent years since, as a consequence of certain business strategies, the "numbers of operations to be completed, the numbers and weights of items to be cleaned, and the effort involved" have all increased, while "flexible employment relationships and outsourcing have also worsened cleaners' workloads" (Seifert \& Messing, 2006: page 557). From a gender point-of-view, "research has identified a clear segmentation of men's and women's work in tourism, showing how the majority of women's work is concentrated in seasonal, part-time, and low-paid activities such as retail, hospitality, and cleaning" (Ferguson, 2011: page 237). Onsøyen and Mykletun (2009) highlight that the main problems experienced at work by hotel room-attendants in Norway include time pressure, a sense of being under close and negative supervision, being undervalued at work, and not being involved in relevant decision-making.

Regarding cleaning times, some professional studies have been conducted in the hotel sector. Siguaw and Enz (1999) cite the case of the Grand Theme Hotels, where a time study was conducted of each of the main hotel activities (e.g., check-in, cleaning an occupied room, serving a meal). Heath (2016) reports a self-conducted time-and-motion study for one of his clients with suite rooms. Other studies offer cleaning time data but do not state how they have been obtained. For example, Falbo (1999) gathers different experiences to improve productivity and cleaning quality in hotels, with times per room provided for some hotels. Seifert and Messing (2006) conduct two ergonomic case studies of cleaning in hotels in Montreal, Canada. Krause et al. (2005) also obtain cleaning times from a survey of 941 unionized hotel room cleaners. Onsøyen and Mykletun (2009) mention a time of 20-30 minutes servicing per room for the room-attendants in four chain-affiliated hotels in Norway. In another part of the paper, they also indicate that each room-attendant was usually expected to clean approx. 17 rooms in a 7-7.5-hour shift, but this number could occasionally rise to 35 rooms on the most hectic days. In an analysis of customer profitability, Dalci, Tanis and Kosan (2010) consider the time spent on different housekeeping activities for various types of hotel customer but do not indicate how it is obtained. Sherman (2011) comments that room cleaners are required to clean 12 rooms per shift at two American luxury urban hotels. All the cleaning times from these preceding studies have been included in Table 1.

Other studies report the number of rooms cleaned per hour. Kirwin (1990) indicates an increase in productivity of 2.5 to 3 rooms per hour up from 2.25 in the previous data. Jones and Siag (2009) provide data for 2.27 rooms cleaned per hour in a productivity study for a chain of 45 hotels in the United Kingdom. As mentioned previously, Mehrez et al. (2000) analyze the case of a single hotel in Israel and its average cleaning time data are also included in Table 1. 


\begin{tabular}{|c|c|c|c|c|}
\hline Paper & $\begin{array}{l}\text { Data collection method } \\
\text { and sample size }\end{array}$ & $\begin{array}{l}\text { Hotel or Chain } \\
\text { analyzed }\end{array}$ & $\begin{array}{l}\text { Room cleaning time } \\
\text { in minutes }\end{array}$ & $\begin{array}{l}\text { No. rooms per } \\
\text { housekeeper per day }\end{array}$ \\
\hline Falbo, 1999 & No data & 5 hotels in USA & $\begin{array}{l}20,18-20,20-25,27 \\
\text { and } 20\end{array}$ & \\
\hline Mehrez et al., 2000 & Observation of 175 rooms & $\begin{array}{l}\text { One Hotel in } \\
\text { Israel }\end{array}$ & $\begin{array}{c}24.31 \text { to } \\
24.81 \text { (stayover) and } \\
42.23 \text { to } 44 \text { (checkout) }\end{array}$ & \\
\hline Krause et al., 2005 & Survey of 941 room cleaners & 5 hotels in USA & - & 15.3 \\
\hline $\begin{array}{l}\text { Seifert \& Messing, } \\
2006\end{array}$ & $\begin{array}{l}\text { Observation of } 18 \text { room } \\
\text { cleaners for } 90 \text { hours }\end{array}$ & $\begin{array}{l}2 \text { large hotels in } \\
\text { Montreal (Canada) }\end{array}$ & $\begin{array}{c}26-28 \text { (Ranked from } \\
15 \text { to } 49)\end{array}$ & $14-15$ \\
\hline $\begin{array}{l}\text { Eriksson \& Li, } \\
2009\end{array}$ & $\begin{array}{l}\text { Interviews and questionnaire to } \\
\text { groups of } 3-5 \text { room-attendants } \\
\text { or to person in charge from } \\
\text { outside company }\end{array}$ & 8 Danish hotels & $\begin{array}{c}15 \text { to } 20 \text { for } \\
\text { outsourced cleaning } \\
\text { and } 20 \text { to } 25 \text { for in- } \\
\text { house. }\end{array}$ & 20 \\
\hline $\begin{array}{l}\text { Onsøyen \& } \\
\text { Mykletun, } 2009\end{array}$ & $\begin{array}{l}13 \text { focus groups interviews with } \\
\text { room-attendants }\end{array}$ & $\begin{array}{l}4 \text { Norwegian } \\
\text { hotels }\end{array}$ & $20-30$ & 17 \\
\hline Dalci et al., 2010 & $\begin{array}{l}\text { Observations in a one-year } \\
\text { period and follow-up interviews }\end{array}$ & $\begin{array}{l}\text { One four-star } \\
\text { hotel in Turkey }\end{array}$ & $\begin{array}{l}4 \text { (stayover), 6-15 } \\
\text { (before check-in), and } \\
16-31 \text { (check-out) }\end{array}$ & \\
\hline Sherman, 2011 & $\begin{array}{l}\text { Participant observation in the } \\
\text { housekeeping department for } \\
120 \text { hours }\end{array}$ & $\begin{array}{l}2 \text { luxury urban } \\
\text { hotels in a major } \\
\text { US city }\end{array}$ & - & 12 \\
\hline Heath, 2016 & Observation of 60 rooms & $\begin{array}{l}\text { One all-suite hotel } \\
\text { in USA }\end{array}$ & $\begin{array}{l}23 \text { (stayover) and } 43 \\
\text { (checkout) }\end{array}$ & \\
\hline
\end{tabular}

Table 1. Room cleaning times collected in previous articles

As can be seen, there appear to be two ways to set room cleaning times: directly, through the identification of the activities carried out during cleaning and their time measurement; and indirectly, through the allocation of a number of rooms per hour or per workday. According to Sherman (2011), the quota is by far the most common way of organizing room cleaning and turndown in the hotel industry. Nevertheless, Edghiem and Mouzughi (2018) explain some of the advantages of the direct method, analyzing the case of a hotel that follows a sequence of 20 steps to clean rooms: it enables better control and efficiency, it is easier to estimate the time spent on each step and identify the weakest areas of performance, and it is possible to control the quality of the cleaning.

Regarding the factors that determine cleaning time, the variables that have been analyzed in the literature can be divided into two groups: those related to the task, such as the condition that the room is in or the way that the hotel organizes the activity, and those related to the attributes or characteristics of the cleaning employees.

\subsection{Task-Related Variables}

These are factors that affect the type of cleaning work to be done and, therefore, the time required for its execution. For example, Mehrez et al. (2000) show that, in general, there are statistically significant differences in room cleaning times depending on the type of room (room type) and the type of cleaning (room cleaning schedule) and establish a model based on these two variables. In the same line, in their ergonomic study of two hotels in Montreal, Canada, Seifert and Messing (2006) find that cleaners' work activity varies considerably depending on the type of room to be cleaned and whether the guest is staying over or not. Jones and Siag (2009) do not consider the characteristics of the cleaning as explanatory variables but, rather, six characteristics of the hotels: Age, Size, Location (Urban or Non-urban), Service level (Two-, Three- or Four-star), Occupancy and Region, and find that the only variable that is significant is the Service level. In the study by Dalci et al. (2010), housekeeping activity times are related to the type of customer (business, through travel agents, "walk-in", etc.) and the point in the customer's stay (before check-in, during the stay, after check-out). 
Onsøyen and Mykletun (2009) point to other aspects that most likely influence room-attendants' work, such as the variation in surface qualities and room design, weight of objects and other attributes (e.g., bed covers, chairs etc.), physical space for cleaning and equipment transport and the practicability and quality of the equipment.

Sherman (2011) emphasizes the role of customers as an influencing factor despite their minimal interaction with housekeepers. She argues that customers affect several non-interactive dimensions of these jobs, including timing, pace, and effort. In particular, guest behavior determines the timing of work, as, for example, the room-attendant cannot enter the room until the guest leaves. The guest's behavior and desires also affect what the workers do once they are able to enter the room, as room cleaning is harder or easier depending on the use that the guest has made of the room. For example, in Sherman's (2011) study room cleaners agreed that occupied rooms (with a stayover guest) were easier to clean than vacant rooms (when the guest has checked out). Likewise, rooms occupied by business travelers were also easier to clean than those occupied by leisure travelers, who spend more time in their rooms and so leave them in greater disarray.

Thus, in this study, we use three variables that should affect cleaning time, two of which have been used in previous investigations (type of room and type of cleaning) while the third has been less studied (the number of rooms assigned), and propose the following three hypotheses:

H1: Room cleaning time is related to room type.

H2: Room cleaning time is related to point in the guest's stay.

H3: Room cleaning time is related to the number of rooms assigned to the employee.

\subsection{Housekeeper-Related Variables}

Another type of factor that can influence cleaning time is related to the characteristics of the employees who execute the task. There are few studies that have analyzed the influence of this type of variable on cleaning time, but it has been used in studies of other aspects of the hotel industry. Age, organizational tenure, and education were included in Xie, Li, Chen and Huan (2016) and in Safavi and Karetepe (2018), for example, and employment status (equivalent to contract type) in McPhail, Patiar, Herington, Creed and Davidson (2015).

With respect to training, Vlijmen (2019) states that it is important to prepare cleaners not only technically (the what and how of cleaning) but also in the social aspects of the work (for whom the cleaning is being done) and encourages face-to-face communication between users and cleaners. Abasabanye et al. (2018) reach this same conclusion, although they also state that contact is virtually impossible in the case of cleaning in hotels. In her study, Sherman (2011) finds that training is rather informal, as room cleaners and turndown attendants are trained by their co-workers. She goes on to explain that this "sink or swim" approach is common in the industry, even when more formal training supposedly exists, and, as a consequence, room cleaners do not necessarily do the major tasks in the same order.

Oxenbridge and Lindegaard-Moensted (2011) find that payment per number of rooms cleaned results in task "speed-up". Onsøyen and Mykletun (2009) also mention that the type of contract or form of payment can influence time: "A couple of hotels employed room-attendants on a fixed-hour-fixed-salary basis, at the same time that the room-attendants were remunerated for every room they cleaned in addition to the fixed number of 17 rooms". Sherman (2011) also notes that some hotels pay cleaners by the room, intensifying work even further and involving guest-generated unpredictability in workers' earnings.

In this study, four employee attributes taken from previous studies are analyzed: age, degree of experience, training, and type of contract. Consequently, we propose the following four hypotheses:

H4: Room cleaning time is related to the employee's age.

H5: Room cleaning time is related to the employee's level of seniority.

H6: Room cleaning time is related to the fact of receiving training.

H7: Room cleaning time is related to the type of employee contract. 


\section{Methodology}

\subsection{Case Study}

The study was conducted in a 4-star hotel in Seville (Spain). The hotel has 74 rooms on 6 floors. From highest to lowest category, the four types of room are: Suite, Superior Standard (double), Standard (double) and Single. The Suite is $37 \mathrm{~m}^{2}$ in size with a living room and a hall; the Superior Standard Room is $27 \mathrm{~m}^{2}$, while the Standard Room is $18 \mathrm{~m}^{2}$, and the Single Room between 12 and $15 \mathrm{~m}^{2}$.

The hotel has established three different types of cleaning: "Checkout", "Stayover with changes", and "Stayover". "Checkout" means that the customer vacates the room and that it needs to be left perfectly ready for the entry of a new customer. "Stayover with changes" means that the customer is going to spend more than three nights in the hotel, so the sheets are changed after the third night. This type of cleaning is not usual in this hotel since it is a business hotel with very short stays. "Stayover" type cleaning means that the customer is going to reuse the room the same day, so the bed is made, and the rest of the room is cleaned, but the sheets are not changed.

Although there are hotels where room cleaning can be performed in teams, in the hotel analyzed it is carried out individually by a single employee. This hotel works with a fixed housekeeper assigned to each floor. This allows better control when assessing the quality and condition of the rooms and helps to maintain stable quality standards. At the same time, the management aims to achieve greater work efficiency with this policy, since the housekeeper knows the status of the rooms on her/his floor, and it enhances the degree of involvement and commitment to work well done. The average monthly salary of a housekeeper is $800 €$ and the working week is 40 hours spread over 5 days.

\subsection{Time Study}

The Time Study is a work-measurement technique used to obtain productivity standards (Fitzsimmons \& Fitzsimmons, 2011) or work standard times. "A work standard is the time for a trained worker, or team of trained workers, to perform a task following a prescribed method with normal effort and skill" (Southern, 1999: page 371). There are several work-measurement techniques (Freivald \& Niebel, 2009: page 405): stopwatch time study, pre-determined time systems, standard data, time formulas, and work sampling studies. As pointed out by Roser (2016), Time Study is at the heart of the scientific management approach developed by Taylor, an approach whose basis "was a detailed understanding of the work to be done, not only qualitatively but also and especially quantitatively" (page 223). The stopwatch time study consists of identifying and measuring individual time elements in repetitive work. These repetitive jobs are also called work cycles or Controllable Jobs (Thompson, 1998a, 1998b). They have been given this last name because there is a degree of control over the execution of this type of work by both managers and employees. In contrast, managers and employees do not have control over Non-Controllable Work, since it depends entirely on the arrival of the customer and requires an immediate response.

Time studies are especially useful in the tourism sector for controllable jobs in which the work is repetitive. In hostelry, cleaning rooms is by nature repetitive work and a controllable job. Other typical types of work of the hotel industry, such as check-in, which involves attending to customers at reception, would be non-controllable, since they can only be conducted, or at least in part, in the presence of the customer, which introduces a factor of high variability. In these cases, another type of study called Work Sampling could be conducted, with the objective of determining how workers distribute their time among several activities. Work Sampling can also be useful for determining how restaurant waiters or amusement park monitors distribute their time, for example.

The present study focuses exclusively on room cleaning and excludes other areas of hotel cleaning that the housekeepers are also responsible for, such as corridors, common areas or lounges. For this, a data collection sheet was designed and used to register the time required to accomplish each of the tasks performed within the room measured by stopwatch, as well as the time spent outside the room, but which forms part of room cleaning per se. The last ones include the times required to load the cleaning trolley with the materials, maintenance of the "office" (room located on the same floor in which the materials and cleaning products are stored), and to throw the dirty linen into the laundry chute, etc.

The study data collection form was presented to each of the housekeepers, and they were told that some questions would be asked to ascertain the profile of each worker. It was explained that the information would be treated 
anonymously, without identifying the worker and without communicating any personal information to the hotel management. This was intended to ensure that no comparison could be made with other workers and that employees could not be harmed professionally, since it was not the aim of the study to assess the performance of any particular worker. The employee was therefore guaranteed to be under little pressure while being observed, and that the study would be more representative of the process that it was intended to measure. During the study, an effort was made to accustom floor housekeepers to the presence of the observer so that they would behave in the most natural way possible, as they would without the presence of a stranger. It was made clear to the personnel that the object of study was limited to the times spent cleaning rooms, and no other jobs performed by the housekeepers or the cleaning quality were to be analyzed.

The person who collected data was trained for understanding the cleaning work to be measured, and to inspire trust, develop a friendly approach to the workers and exercise judgement. Measurements have been made of all hotel housekeeping employees so that the study is representative of this worker group.

To calculate the number of observations to be made, it was assumed that this was a normal population of infinite size and, therefore, the sample size needed to estimate the population mean was measured by the formula (adapted from Freivalds \& Niebels, 2009: page 431):

$$
n=\left(Z_{1-\alpha / 2} \frac{s}{\epsilon \bar{x}}\right)^{2}
$$

Where: $n=$ sample size or number of observations, $s=$ sample standard deviation, $\bar{x}=$ sample mean, $Z=$ the value in normal distribution that corresponds to the desired confidence level $(95 \%$ was chosen as this is a normal level in studies of this nature), and $\epsilon=$ the margin of error, set at a fraction of $\pm 5 \%$ of $\bar{x}$, which again is usual in this type of study.

10 observations of cleaning times were made to obtain the mean and standard deviation in the above formula. The resulting sample size was 74 observations of cleanings, so, as there were 8 staff employees, it was decided to make 9 observations per employee. 10 observations were made of 2 of the employees to reach a total of 74 observations.

Rooms to be measured were randomly selected each day. Measurement was done on different days and at different times to be able to observe all the personnel in the housekeeping department, both permanent and temporary. Table 2 shows the number of rooms observed in the study by category and cleaning type. It can be observed that few rooms have needed "stayover with changes" cleaning since, as mentioned, this type of cleaning is only done for customers who stay for longer than three nights. The number of rooms requiring "stayover" cleaning and "checkout" cleaning are practically the same.

\begin{tabular}{|c|c|c|c|c|}
\hline \multirow[b]{2}{*}{ Room category } & \multicolumn{3}{|c|}{ Cleaning type } & \multirow[b]{2}{*}{ Total } \\
\hline & Stayover & $\begin{array}{c}\text { Stayover with } \\
\text { changes }\end{array}$ & Checkout & \\
\hline Single & & & 2 & 2 \\
\hline Standard & 28 & 1 & 23 & 52 \\
\hline Superior Standard & 4 & 1 & 9 & 14 \\
\hline Suite & 3 & 1 & 2 & 6 \\
\hline Total & 35 & 3 & 36 & 74 \\
\hline
\end{tabular}

Table 2. Number of observations by room category and cleaning type

To address the first of our objectives, our analysis includes the calculations of the average values of the data collected in the study of times for each of the tasks done as part of room cleaning and total time. Average total cleaning times per room type and cleaning type have also been calculated. Excel spreadsheet was used for the analysis. 


\subsection{Regression Analysis}

The variables related to cleaning time that, according to the previous literature, were measured in this study are:

- Room type: (1) single, (2) standard, (3) superior standard, and (4) suite.

- Cleaning type: (1) stayover, (2) occupied with changes, and (3) checkout.

- Number of rooms assigned per day: 13,15, 16 or 19.

- Cleaner's age: (1) under 30 years, (2) 30—39 years, and (3) 40-49 years.

- Cleaner's seniority in the company: (1) under 5 years, (2) 5-9 years, and (3) 10—14 years.

- Previous training in housekeeping tasks: (0) no training, and (1) training.

- The type of employment contract: (0) temporary or (1) permanent.

Table 3 reports the percentages of rooms observed according to the characteristics of the housekeeping personnel.

\begin{tabular}{|c|c|c|}
\hline Factor & Attribute or variable & Percentage in sample \\
\hline \multirow{3}{*}{ Age } & Under 30 years & 20 \\
\hline & $30-39$ years & 35 \\
\hline & $40-49$ years & 45 \\
\hline \multirow{3}{*}{ Seniority } & Under 5 years & 20 \\
\hline & $5-9$ years & 35 \\
\hline & $10-14$ years & 45 \\
\hline \multirow{2}{*}{ Training } & No training & 38 \\
\hline & Trained & 62 \\
\hline \multirow{2}{*}{$\begin{array}{l}\text { Type of employment } \\
\text { contract }\end{array}$} & Permanent & 54 \\
\hline & Temporary & 46 \\
\hline \multirow{4}{*}{ Rooms per day } & 13 & 9 \\
\hline & 15 & 18 \\
\hline & 16 & 15 \\
\hline & 19 & 58 \\
\hline
\end{tabular}

Table 3. Observations ( $\%)$ by cleaning staff characteristics $(n=74)$

Table 3 shows that most of the rooms were made up by staff aged between 40 and 49 years and with an experience of 10 to 14 years. Regarding the number of rooms per day, the most common value is that employees make up 19 rooms, which is the number usually assigned to a worker with a working day of 8 hours. Fewer rooms are usually assigned to workers on a reduced working-day with nursery hours (5 hours, 13 rooms), and those who have a kind of zero-hour contracts (6 hours, 15 rooms) and whose relationship with the company is temporary.

A descriptive analysis was performed previously using the data obtained in the observations to determine means, dispersion measures and different graphs for the studied variables. For our second objective, multiple linear regression analysis has been conducted with cross-sectional data. This analysis was performed with SPSS v.24 statistical software. The dependent or explained variable was the time spent cleaning (the total time without extras, measured in seconds), since extras are irregular and unpredictable. All seven variables included in the study were initially considered as independent or explanatory variables: Age, Seniority, Training, Contract Type, Room Category, Cleaning Type and Rooms assigned per day. Two of these were dichotomous (Contract Type, and Training); two, ordinal variables (Room Category and Cleaning Type); and the remaining were considered continuous (Age, Seniority, and Rooms assigned per day). Age and Seniority were codified using the middle values of the intervals (i.e., class midpoints). 
Although sufficient, the number of available observations was not high, so it was decided to perform a sequential regression by dividing the variables into two blocks: the employee-related variables and the task-related variables. We first considered a Model 1 with all the variables related to employee characteristics (Age, Seniority, Training and Contract Type). Then, we considered a Model 2 for the variables related to cleaning task that were detected in the prior literature: Room Category and Cleaning Type, plus the Number of Rooms assigned per day. Our analysis strategy consisted of checking what employee-related variables were significant in Model 1 in order to include only those ones in the second model (Model 2). The models to be estimated are, therefore:

Model 1:

$$
\begin{aligned}
& Y_{i}=\beta_{0}+\beta_{1} X_{1 i}+\beta_{2} X_{2 i}+\beta_{3} X_{3 i}+\beta_{4} X_{4 i}+\varepsilon_{i} \\
& i=1,2, \ldots, n ; \varepsilon_{i} \in N\left(0, \sigma^{2}\right) ; \operatorname{cov}\left(\varepsilon_{i}, \varepsilon_{i}\right)=0, i \neq j .
\end{aligned}
$$

Where, $Y_{i}=$ Total cleaning time without extras, $X_{1}=$ Age, $X_{2}=$ Seniority, $X_{3}=$ Training, and $X_{4}=$ Contract type.

Model 2:

$$
\begin{aligned}
& Y_{i}=\beta_{0}+\beta_{1} X_{1 i}+\beta_{2} X_{2 i}+\beta_{3} X_{3 i}+\cdots+\varepsilon_{i} \\
& i=1,2, \ldots, n ; \varepsilon_{i} \in N\left(0, \sigma^{2}\right) ; \operatorname{cov}\left(\varepsilon_{i}, \varepsilon_{i}\right)=0, i \neq j .
\end{aligned}
$$

Where, $Y_{i}=$ Total cleaning time without extras, $X_{1}=$ Room category, $X_{2}=$ Cleaning type, and $X_{3}=$ Number of rooms assigned. The ellipses indicate the variables of Model 1 that are significant.

\section{Results}

\begin{tabular}{|c|c|c|c|c|c|}
\hline Tasks & $\mathbf{N}$ & Total time in sample & $\%$ of total time & Average time & Std. dev. \\
\hline Making the bed & 74 & 303.32 & $22.97 \%$ & 4.10 & 1.73 \\
\hline Bedside tables and tables & 74 & 181.18 & $13.72 \%$ & 2.45 & 1.27 \\
\hline Washbasin. mirror and shower screen & 74 & 175.57 & $13.29 \%$ & 2.37 & 1.18 \\
\hline Scrubbing bathroom floor & 73 & 128.52 & $9.73 \%$ & 1.76 & 1.00 \\
\hline Hoovering & 73 & 112.93 & $8.55 \%$ & 1.55 & 0.57 \\
\hline Gathering bed linen & 67 & 93.90 & $7.06 \%$ & 1.39 & 0.88 \\
\hline Replacing towels & 73 & 73.25 & $5.55 \%$ & 1.00 & 0.53 \\
\hline Cleaning bathtub & 70 & 72.00 & $5.45 \%$ & 1.03 & 0.82 \\
\hline Removing used and dirty bathroom items & 73 & 50.75 & $3.84 \%$ & 0.70 & 0.50 \\
\hline Soaping and rinsing toilet and bidet & 74 & 47.58 & $3.6 \%$ & 0.64 & 0.44 \\
\hline Stripping the bed & 37 & 37.63 & $2.85 \%$ & 1.02 & 0.49 \\
\hline Replacing amenities & 59 & 23.77 & $1.80 \%$ & 0.40 & 0.38 \\
\hline Removing dirty bed linen & 68 & 12.32 & $0.93 \%$ & 0.18 & 0.19 \\
\hline Shower & 6 & 8.62 & $0.65 \%$ & 1.44 & 0.73 \\
\hline Total times without extras & 74 & $1,320.73$ & $100.0 \%$ & 17.85 & 5.02 \\
\hline Total times with extras & 74 & $1,370.37$ & & 18.52 & 6.69 \\
\hline
\end{tabular}

\subsection{Time Study Results}

Table 4 presents some descriptive statistics of room cleaning tasks listed from greatest to least total time in the sample.

Table 4. Descriptive statistics of room cleaning times (in minutes) 
Total times without extras correspond to routine tasks involved in room cleaning. Total times with extras include some extra tasks entrusted to the housekeepers that are not routine or usual, such as cleaning liquid spills, picking up a guest's clothes, etc. These times have been separated so that extras do not distort measurement. However, extras, and also idle or rest times, must be included in total times when estimating work standard times (WST). To set the WST, it is also necessary to consider the pace of work developed by the worker in each observation (Freivalds \& Niebel, 2009; Fitzsimmons \& Fitzsimmons, 2011). However, the objective of this work is not to calculate the WST for hotel management but to analyze the cleaning time and the variables that can influence it.

As for the tasks, it can be seen in Table 4 that the task that requires the most time is "making bed" (23.0\% of the total time), followed by cleaning "bedside tables and tables", "bathroom sink, mirror and shower screen", "scrubbing bathroom floor" and "hoovering." These 5 tasks together make up $68.24 \%$ of the total time. The data for most of the measured times show moderate standard deviations.

Table 5 shows average total times without extras by cleaning type and room type. It is interesting to see how much time is spent cleaning each type of room, and the time that it takes to perform each of the different types of cleaning in the various room categories. The table clearly shows that the higher the category of room, the more time is required. Likewise, it shows how time increases as the type of room cleaning required changes from "stayover" to "checkout".

\begin{tabular}{|l|r|r|r|r|}
\hline \multirow{2}{*}{ Room category } & \multicolumn{3}{|c|}{ Cleaning type } & Total \\
\cline { 2 - 5 } & Stayover & $\begin{array}{c}\text { Stayover with } \\
\text { changes }\end{array}$ & Checkout & $\begin{array}{c}\text { Totage time } \\
\text { averagen }\end{array}$ \\
\hline Single & 14.79 & 15.60 & 19.48 & 15.48 \\
\hline Standard & 16.26 & 16.98 & 21.81 & 16.96 \\
\hline Superior Standard & 18.16 & 21.95 & 26.59 & 19.88 \\
\hline Suite & $\mathbf{1 5 . 2 4}$ & $\mathbf{1 8 . 1 8}$ & $\mathbf{2 0 . 3 5}$ & $\mathbf{1 7 . 8 5}$ \\
\hline Total average time & & & 19.60 \\
\hline
\end{tabular}

Table 5. Average total times in minutes without extras by cleaning and room type

\subsection{Regression Analysis Results}

Table 6 shows the results of the first regression model, which only includes the employee-related variables.

\begin{tabular}{|c|c|c|c|c|c|c|}
\hline \multirow{2}{*}{\multicolumn{2}{|c|}{ Model 1* }} & \multicolumn{2}{|c|}{ Non-standardized Coefficients } & \multirow{2}{*}{$\begin{array}{c}\text { Standardized Coefficients } \\
\text { Beta }\end{array}$} & \multirow[b]{2}{*}{$\mathbf{t}$} & \multirow[b]{2}{*}{ Sig. } \\
\hline & & B & Std. error & & & \\
\hline \multicolumn{2}{|c|}{ (Intercept) } & 906.19 & 253.17 & & 3.853 & .000 \\
\hline \multicolumn{2}{|l|}{ Age } & 3.77 & 5.69 & .097 & 0.663 & .510 \\
\hline \multicolumn{2}{|l|}{ Seniority } & -0.57 & 9.87 & -.007 & -0.058 & .954 \\
\hline \multicolumn{2}{|l|}{ Training } & 127.06 & 84.35 & .206 & 1.506 & .137 \\
\hline \multicolumn{2}{|l|}{ Contract } & -92.59 & 74.94 & -.154 & -1.235 & .221 \\
\hline $\mathbf{R}$ & & \multicolumn{2}{|c|}{ Adjusted $\mathbf{R}^{2}$} & \multicolumn{3}{|c|}{ Standard error of the estimate } \\
\hline .234 & .055 & & .000 & & & 301.47 \\
\hline
\end{tabular}

* Dependent variable: Total cleaning time without extras

Table 6. Model 1. Linear regression analysis with worker-related variables 
As can be seen, none of these variables is statistically significant and, in addition, the percentage of variance explained by the model $\left(R^{2}\right)$ is practically nil. Thus, we can discard all these variables and, consequently, Model 2 will only include the task-related variables. Table 7 shows the results of regression Model 2.

\begin{tabular}{|c|c|c|c|c|c|c|}
\hline \multirow{2}{*}{\multicolumn{2}{|c|}{ Model 2* }} & \multicolumn{2}{|c|}{ Non-standardized Coefficients } & \multirow{2}{*}{$\begin{array}{c}\text { Standardized Coefficients } \\
\text { Beta }\end{array}$} & \multirow[b]{2}{*}{ t } & \multirow[b]{2}{*}{ Sig. } \\
\hline & & B & Std. error & & & \\
\hline \multicolumn{2}{|l|}{ (Intercept) } & $1,159.10$ & 286.82 & & 4.041 & .000 \\
\hline \multicolumn{2}{|c|}{ Room category: Standard } & 273.94 & 177.05 & .418 & 1.547 & .127 \\
\hline \multicolumn{2}{|c|}{ Room cat:: Superior Standard } & 386.16 & 183.89 & .505 & 2.100 & .040 \\
\hline \multicolumn{2}{|c|}{ Room category: Suite } & 608.11 & 202.35 & .554 & 3.005 & .004 \\
\hline \multicolumn{2}{|c|}{ Cleaning: Stayover with changes } & 133.46 & 150.70 & .088 & 0.886 & .379 \\
\hline \multicolumn{2}{|c|}{ Cleaning: Checkout } & 328.28 & 59.42 & .548 & 5.525 & .000 \\
\hline \multicolumn{2}{|c|}{ Number of rooms assigned } & -32.88 & 13.41 & -.236 & -2.451 & .017 \\
\hline $\mathbf{R}$ & $\mathbf{R}$ squared & \multicolumn{2}{|c|}{ Adjusted R squared } & \multicolumn{3}{|c|}{ Standard error of the estimate } \\
\hline .641 & .411 & & .358 & & & 241.40 \\
\hline
\end{tabular}

* Dependent variable: Total cleaning time without extras

Table 7. Model 2. Linear regression analysis with the cleaning task-related variables

The three variables included in the model are statistically significant. In Room Category, cleaning time increases over the "Single" benchmark category are significant for "Superior Standard" and "Suite", but not for "Standard". In the cleaning category, there is a significant time increase for the "Checkout" category compared to the "Stayover" benchmark category, but not for "Stayover with changes". Number of rooms assigned has a negative and statistically significant coefficient, which means that, for each additional room assigned, the cleaning time is reduced by almost 33 seconds or half a minute.

The ANOVA of this model confirms that when the two ordinal variables are contrasted jointly, i.e., considering all their levels together, they are statistically significant $(F(3,67)=4.062, \mathrm{p}=0.01$, for Room Category, and $\mathrm{F}(2,67)=14.297, \mathrm{p}<0.001$, for Cleaning type $)$.

The analysis of the residuals of this regression model suggests that there are no violations of the assumptions of normality, linearity, and homoscedasticity. The inspection of Mahalanobis distances and standardized residuals do not indicate the existence of significant outliers. Moreover, Cook's distances do not show any influential case to be highlighted. Neither of the two models exhibits multicollinearity problems, as the maximum VIFs are 1.56 in Model 1 and 1.03 in Model 2.

\section{Discussion, Implications and Limitations}

\subsection{Discussion}

Regarding the first objective of this work, the average estimated time for cleaning a room in our study was about 18 minutes. However, the average time varies between 15 minutes for stayover standard room cleaning, and 27 for checkout suite cleaning. These times are below what was obtained in previous studies (see Table 1). As for the individual tasks, five of them ("making bed", cleaning "bedside tables and tables", "washbasin, mirror and shower screen", "scrubbing bathroom floor" and "hoovering") jointly represent over $2 / 3$ of the total time required for cleaning.

The second objective of this article was to determine the variables that influence total room cleaning time in a hotel. The linear statistical model obtained through the regression analysis has shown that these variables are room category, cleaning type, and the number of rooms assigned to the employee. The study has also shown that, in our 
case study at least, housekeeper-related variables such as age, seniority, training or the type of contract (permanent or temporary) do not influence cleaning time.

\subsection{Theoretical Implications}

This study makes some contributions on the academic level that may prove interesting. First, the study underscores and demonstrates the utility of Time Study as a management technique, despite which, they are not usually used in this sector. The application of a time study here has allowed to highlight the tasks consuming most cleaning time. Despite their limited use, the need to conduct Time Studies in Tourism Sector research has become apparent, given their importance in the development of modern industry (Roser, 2016). As Mehrez et al. (2000: page 360) point out, "the abandonment of work measurement techniques suggests that many organizations no longer know how much time is required to produce their products or services, a fact that may reduce long-run performance and competitiveness". In hospitality, work standards and service task time are needed to determine the number of employees required, to simulate queuing situations, and to evaluate the performance of a service system (Southern, 1999).

Meanwhile, the regression analysis has allowed us to determine the variables that influence cleaning time. The study proves that employee-related variables have no influence on cleaning time. This can be considered new information as not all of this study's variables have been applied in previous studies. The finding that room category and cleaning type affect cleaning time is in line with previous studies (Mehrez et al., 2000; Seifert \& Messing, 2006), although empirical studies that prove this relationship are very scarce in the literature. However, the third variable that was significant in the present study, the number of rooms assigned per employee, is rather more groundbreaking.

It is important to highlight that the number of rooms assigned to an employee per day variable is a determinant of cleaning time with a negative coefficient. This means that the housekeepers reduce time per room when they are assigned more rooms, with the evident objective of not extending their workday beyond what they have been contracted and paid for. This can be a major problem for the health and safety of hotel cleaners at work (Seifert \& Messing, 2006). Hsieh, Apostolopoulos and Sönmez (2016) stated that time pressure caused by rushing to clean rooms puts great stress on workers and harms their psychological wellness. They go on to describe how hotel housekeepers are exposed to a wide range of occupational hazards that have a negative effect on their health. Kensbock, Jennings, Bailey and Patiar (2016) define room attending as "a predominantly female occupation involving physically and psychologically hard work, low status and minimal pay" (page 115), and describe a number of physical and psychological stressors that are likely to impact on their wellbeing and performance. Previous studies have shown that this sector has one of the highest levels of risk for workers. For example, Krause et al. (2005) state that occupational injury rates among hotel workers exceed the national service sector average. These authors assess the prevalence of back and neck pain linked to physical workload, ergonomic issues, and increasing work demands. In a 1999-2005 study of 40,030 employees at 87 unionized hotels in the US, Frumin et al. (2006) states that there is a $61 \%$ greater risk of injury to housekeepers than to other hotel employees. In response to these data, in some cases, "the labor union representing cleaners has negotiated a lower number of room assignments per cleaner, as well as improvements to the way that work variability is taken into account when determining the quota of rooms to be cleaned" (Seifert \& Messing, 2006: page 557). The importance of controlling the workload is not limited only to workers' health but also to quality and absenteeism (Frumin et al., 2006), which clearly affect a hotel's productivity and, consequently, its economic results.

\subsection{Practical Implications}

It was seen that five individual tasks jointly represent over $2 / 3$ of the total time required for cleaning, and so, if it is wished to obtain any improvements in the process and time controls, the management and employees should focus on these tasks ("bed making", cleaning "bedside tables and tables", "washbasin, mirror and shower screen", "scrubbing bathroom floor" and "hoovering"). At the same time, specific training should be provided for these tasks and hotel designers could focus on them when planning facilities. 
It has also been shown how Time Study can be used for planning and scheduling room cleaning and employees and what variables should be considered. This will allow staff numbers to be properly fitted to the hotel's requirements and the best combination of personnel to be determined, bearing in mind that temporary personnel are informed of the hours of service that are required of them on a day-to-day basis. The management must be aware that this activity needs to be properly planned as it affects its productivity and quality, as well as the satisfaction of the employees who perform it.

One practical contribution made by this study is that it shows that assign a specific number of rooms to cleaners could not be the best way to organize this hotel activity. Hotels have to know how much time is required to clean each of the rooms according to room type and required type of cleaning. On many occasions, however, managers are not mindful of these issues when assigning the number of rooms to be cleaned during the workday. It is therefore proposed that the use of Time Study be generalized so the planning task can be undertaken more scientifically in hotels. Among the main advantages of this technique, it can be mentioned the following:

- The reliable estimation of room delivery time to customers.

- The required personnel to be determined according to expected room demand.

- The real cost of the analyzed process (personnel and materials) to be found, which will act as the basis for price calculation.

- Rewards and incentives to be set in the Housekeeping department.

- A basis for comparisons with similar category hotels.

- Improvements to be proposed that result in greater satisfaction and safety for workers, a reduction of operating times and higher quality of service.

\subsection{Limitations and Future Lines of Research}

The main limitation of our study comes from its having been conducted of a single hotel establishment, which prevents conclusions being applied more widely. Future studies of other hotels could also be used to compare the influence on the cleaning time of cleaning methods, type of organization, hotel category, cleaning materials and equipment used, etc.

It would have been desirable for this study of methods and times to have been done in conjunction with a study of service quality, with observations of both the quality of room cleaning and the time spent cleaning. In short, if the organization implements a quality control system, it should be linked with the time required to clean the room to determine the best time-quality ratio.

In other respects, it would be very interesting to discover the degree of customer satisfaction and customers' opinions regarding shortcomings that they happen upon in hotel rooms and any possible improvements that can be made.

\section{Declaration of Conflicting Interests}

The authors declared no potential conflicts of interest with respect to the research, authorship, and/or publication of this article.

\section{Funding}

The publication of this article was funded by G.I.D.E.A.O. Research Group (SEJ415).

\section{References}

Abasabanye, P., Bailly, F., \& Devetter, F.X. (2018). Does Contact Between Employees and Service Recipients Lead to Socially More Responsible Behaviours? The Case of Cleaning. Journal of Business Ethics, 153, 813-824. https://doi.org/10.1007/s10551-016-3390-5

Boon, B. (2007). Working within the front-of-house/back-of-house boundary: Room attendants in the hotel guest room space. Journal of Management and Organization, 13(2), 160-174. https://doi.org/10.5172/jmo.2007.13.2.160 
Chen, W.J., \& Chen, M.L. (2014). Factors Affecting the Hotel's Service Quality: Relationship Marketing and Corporate Image. Journal of Hospitality Marketing \& Management, 23(1), 77-96.

https://doi.org/10.1080/19368623.2013.766581

Dalci, I., Tanis, V., \& Kosan, L. (2010). Customer profitability analysis with time-driven activity-based costing: A case study in a hotel. International Journal of Contemporary Hospitality Management, 22(5), 609-637. https://doi.org/10.1108/09596111011053774

Edghiem, F., \& Mouzughi, Y. (2018). Knowledge-advanced innovative behaviour: A hospitality service perspective. International Journal of Contemporary Hospitality Management, 30(1), 197-216. https://doi.org/10.1108/IJCHM-04-20160200

Eriksson, T., \& Li, J. (2009). Working at the boundary between market and flexicurity: Housekeeping in Danish hotels. International Labour Review, 148(4), 357-373. https://doi.org/10.1111/j.1564-913X.2009.00068.x

Espino-Rodríguez, T., \& Ramírez-Fierro, J.C. (2017). Factors determining hotel activity outsourcing. An approach based on competitive advantage. International Journal of Contemporary Hospitality Management, 29(8), $2006-2036$. https://doi.org/10.1108/IJCHM-05-2016-0291

Falbo, B. (1999). Room cleanliness remains key to garnering repeat business. Hotel and Motel Management, September 6, 60-61.

Fitzsimmons, J.A., \& Fitzsimmons, M.A. (2011). Service Management: Operations, Strategy and Information Technology. Singapore: Mc Graw Hill.

Ferguson, L. (2011). Promoting gender equality and empowering women? Tourism and the third Millennium Development Goal. Current Issues in Tourism, 14(3), 235-249. https://doi.org/10.1080/13683500.2011.555522

Freivalds, A., \& Niebel, B.W. (2009). Niebel's Methods, Standards and Work Design (12th ed.). Boston, USA: McGraw-Hill Higher Education.

Frumin, E., Moriarty, J., Vossenas, P., Halpin, J., Orris, P, Krause, N. et al. (2006). Workload-related musculoskeletal disorders among hotel housekeepers: Employee records reveal a growing national problem. Paper presented at the NIOSH 2006 National Occupational Research Agenda Symposium. Washington, DC.

Goggins, R. (2007). Hazards of Cleaning: Strategies for reducing exposures to ergonomic risk factors. Professional Safety, 20-27.

Gundersen, M.G., Heide, M., \& Olsson, U.H. (1996). Hotel guest satisfaction among business travelers: What Are the Important Factors? Cornell Hotel and Restaurant Administration Quarterly, 37(2), 72-81.

https://doi.org/10.1177\%2F001088049603700222

Hartline, M.D, Wooldridge, B.R., \& Jones, K.C. (2003). Guest perceptions of hotel quality: Determining which employee groups count most. Cornell Hotel and Restaurant Administration Quarterly, 44(1), 43-52. http://dx.doi.org/10.1016\%2FS0010-8804(03)90035-8

Heath, B.D.W. (2016). Housekeeping best practices help improve productivity. HotelManagement.net, January, 20.

Hsieh, Y.H., \& Chuang, I.C. (2020). Evaluation of key factors for service experience: A comparison of tourism factories and international tourism hotels. Tourism Economics, 26(3), 404-436. https://doi.org/10.1177/1354816619840099

Hsieh, Y.C., Apostolopoulos, Y., \& Sönmez, S. (2016). Work Conditions and Health and Well-Being of Latina Hotel Housekeepers. Journal of Immigrant and Minority Health, 18(3), 568-581. https://doi.org/10.1007/s10903-015-0224-y

Jones, P. \& Siag, A. (2009). A Re-Examination of the Factors That Influence Productivity in Hotels: A Study of the Housekeeping Function. Tourism and Hospitality Research, 9(3), 224-234. https://doi.org/10.1057\%2Fthr.2009.11

Kensbock, S., Jennings, G., Bailey, J., \& Patiar, A. (2016). Performing: Hotel room attendants' employment experiences. Annals of Tourism Research, 56, 112-127. https://doi.org/10.1016/j.annals.2015.11.010 
Kirwin, P. (1990). A Cost-Saving Approach to Housekeeping. Cornell Hotel and Restaurant Administration Quarterly, 31(3), 25-27. https://doi.org/10.1177\%2F001088049003100308

Krause, N., Scherzer, T., \& Rugulies, R. (2005). Physical workload, work intensification, and prevalence of pain in low wage workers: results from a participatory research project with hotel room cleaners in Las Vegas. American Journal of Industrial Medicine, 48(5), 326-337. https://doi.org/10.1002/ajim.20221

Lewis, B.R. \& McCann, P. (2004). Service failure and recovery: Evidence from the hotel industry. International Journal of Contemporary Hospitality Management, 16(1), 6-17. https://doi.org/10.1108/09596110410516516

Lockyer, T. (2003). Hotel cleanliness-How do guests view it? Let us get specific. A New Zealand study. International Journal of Hospitality Management, 22, 297-305. https://doi.org/10.1016/S0278-4319(03)00024-0

Manhas, P.S. (2015). Understanding service experience and its impact on brand image in hospitality sector. International Journal of Hospitality Management, 45, 77-87. https://doi.org/10.1016/j.ijhm.2014.11.010

McPhail, R., Patiar, A., Herington, C., Creed, P., \& Davidson, M. (2015). Development and initial validation of a hospitality employees' job satisfaction index: Evidence from Australia. International Journal of Contemporary Hospitality Management, 27(8), 1814-1838. https:// doi.org/10.1108/IJCHM-03-2014-0132

Mehrez, A., Israeli, A., \& Haddad, Y. (2000). A work measurement application for hotel housekeeping management. Tourism Economics, 6(4), 359-371. https://doi.org/10.5367\%2F000000000101297686

Nicolau, J.L., \& Sellers, R. (2011). The Effect of Quality on Hotel Risk. Tourism Economics, 17(1), 39-52. https://doi.org/10.5367/te.2011.0021

OICA - International Organization of Motor Vehicle Manufacturers (2016). 2016 Production Statistics. Available at http://www.oica.net/category/production-statistics// (Accessed: May 2017).

Onsøyen, L.E., \& Mykletun, R.J. (2009). Silenced and Invisible: The Work- experience of Room-attendants in Norwegian Hotels. Scandinavian Journal of Hospitality and Tourism, 9(1), 81-102. https://doi.org/10.1080/15022250902761462

Oxenbridge, S., \& Lindegaard-Moensted, M. (2011). The relationship between payment systems work intensification and health and safety outcomes a study of hotel room attendants. Policy and Practice in Health and Safety, 9(2), 7-26. https://doi.org/10.1080/14774003.2011.11667759

Pereira-Moliner, J., \& Tarí, J.J. (2015). Quality Certification, Performance and Size in Hotel Chains. Tourism Economics, 21(2), 307-324. https://doi.org/10.5367\%2Fte.2013.0352

Pongsiri, K. (2012). Housekeeping, Human Resources: Competency Service Standard Management for Hotel Business in ASEAN. International Journal of e-Education, e-Business, e-Management and e-Learning, 2(5), 343-347. https://doi.org/10.7763/IJEEEE.2012.V2.143

Robinson R.N.S., Kralj, A., Solner, D.J., Goh, E., \& Callan V.J. (2016). Attitudinal similarities of hotel frontline occupations. International Journal of Contemporary Hospitality Management, 28(5), 1051-1072. https://doi.org/10.1108/IJCHM-08-2014-0391

Roser, C. (2016). Faster, better, cheaper in the history of manufacturing. Boca Raton, FL, USA: CRC Press.

Safavi, H.P., \& Karatepe, O.M. (2018). High-performance work practices and hotel employee outcomes: The mediating role of career adaptability. International Journal of Contemporary Hospitality Management, 30(2), 1112-1133. https://doi.org/10.1108/IJCHM-07-2016-0367

Seifert, A.M., \& Messing, K. (2006). Cleaning Up After Globalization: An Ergonomic Analysis of Work Activity of Hotel Cleaners. Antipode, 38, 557-578. https://doi.org/10.1111/j.0066-4812.2006.00595.x

Sherman, R. (2011). Beyond interaction: Customer influence on housekeeping and room service work in hotels. Work, Employment and Society, 25(1), 19-33. https:/ /doi.org/10.1177/0950017010389240 
Siguaw, J.A. \& Enz, C.A. (1999). Best practices in hotel operations. Cornell Hotel and Restaurant Administration Quarterly, 40(6), 42-53.

Soni-Sinha, U., \& Yates, C.A.B. (2013). 'Dirty Work?’ Gender, Race and the Union in Industrial Cleaning. Gender, Work and Organization, 20(6), 15. https://doi.org/10.1111/gwao.12006

Southern, G. (1999). A systems approach to performance measurement in hospitality. International Journal of Contemporary Hospitality Management, 11(7), 366-376. https://doi.org/10.1108/09596119910293277

Thompson, G. (1998a). Labor scheduling, Part 1: Forecasting Demand. Cornell Hotel and Restaurant Administration Quarterly, 39(5), 22-31. https://doi.org/10.1177\%2F001088049803900507

Thompson, G. (1998b). Labor scheduling, Part 2: Knowing How Many On-duty Employees to Schedule. Cornell Hotel and Restaurant Administration Quarterly, 39(6), 26-37. https://doi.org/10.1177\%2F001088049803900607

Vlijmen, J. van. (2019). Being a cleaner in The Netherlands: Coping with the dirty work stigma. Facilities, 37(5/6), 280-291. https://doi.org/10.1108/F-03-2018-0038

World Tourism Organization (2017). Compendium of Tourism Statistics dataset [Electronic]. UNWTO, Madrid, data updated on 11/01/2017. Available at: http://www.e-unwto.org/toc/unwtotfb/current (Accessed with subscription: April 2017).

Xie, L., Li, Y., Chen, S.H., \& Huan, T.C. (2016). Triad theory of hotel managerial leadership, employee brand-building behavior, and guest images of luxury-hotel brands. International Journal of Contemporary Hospitality Management, 28(9), 1826-1847. https://doi.org/10.1108/IJCHM-01-2015-0004

Zemke, D.M.V., Neal, J., Shoemaker, S., \& Kirsch, K. (2015). Hotel cleanliness: Will guests pay for enhanced disinfection? International Journal of Contemporary Hospitality Management, 27(4), 690-710.

https://doi.org/10.1108/IJCHM-01-2014-0020

Zock, J.P. (2005). World at work: Cleaners. Occupational \& Environmental Medicine, 62, 581-584.

https://doi.org/10.1136/oem.2004.015032

Journal of Industrial Engineering and Management, 2021 (www.jiem.org)

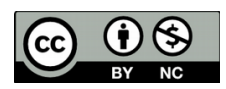

Article's contents are provided on an Attribution-Non Commercial 4.0 Creative commons International License. Readers are allowed to copy, distribute and communicate article's contents, provided the author's and Journal of Industrial Engineering and Management's names are included. It must not be used for commercial purposes. To see the complete license contents, please visit https://creativecommons.org/licenses/by-nc/4.0/. 